\title{
Technical Efficiency and the Factors that Affect it in Rice Production in Central Sulawesi of Indonesia
}

\author{
Muhardi ${ }^{1}$, Effendy $^{2}$ \\ ${ }^{1}$ Department of Agrotechnology, Agriculture Faculty of Tadulako University, Palu, Indonesia \\ ${ }^{2}$ Department of Agriculture Economics, Agriculture Faculty of Tadulako University, Palu, Indonesia \\ * muhardi_hasanuddin@yahoo.com
}

Received: January 21, 2021. Revised: April 12, 2021. Accepted: April 14, 2021. Published: April 16, 2021.

\begin{abstract}
Most of the population of Asia depends on consuming rice to support their lives. This implies that rice production needs attention. The existence of inefficiencies in lowland rice production could reduce rice yields for consumption, so the measurement of technical efficiency in lowland rice production needed to be studied. This research aimed to analyze the level of technical efficiency in lowland rice cultivation and identify the factors that affected it. The research was done in Palolo and Torue Sub-District Indonesia. The number of samples used was 249 lowland rice farmlands consisting of 106 farmers of organic lowland rice cultivation and 143 farmers of inorganic lowland rice cultivation. The results show that land, fertilizer, seeds, and labor had a positive and significant effect on lowland rice production. The average technical efficiency of lowland rice cultivation was around $78.2 \%$. The results also show that manager education, extension contacts, superior seeds, and organic lowland rice cultivation have a significant effect on the level of technical efficiency in lowland rice production. We concluded that there was an opportunity for farmers to increase lowland rice yields if they could manage production factors in an efficient manner. The government could provide support for farmers, such as formal and informal education, extension, superior seeds, and readyto-use organic materials.
\end{abstract}

Key-Words: - organic rice, yields in lowlands, rice farmers, rice cultivation

\section{INTRODUCTION}

The world's rice consumption increased alongside the increase in global population, as is the case in Indonesia. There, rapid population increase demanded the availability of rice in sufficient quantities, adequate quality, and with a quick cultivation time. This need encouraged the emergence of a modern agricultural system characterized by a high dependence on fertilizers and pesticides with synthetic chemicals [1,2].

The use of chemical inputs, however, would reduce the level of soil fertility, decrease biodiversity and increase the attack on pests, diseases, and weeds [3]. Another negative impact was the contamination of agricultural products by chemical materials which, in turn. would have a negative impact on human health [4,5]. Public awareness of the dangers to health and the environment caused a shift in cultivation to an organic system [6]. Organic farming became part of the latest efforts to promote agricultural systems that were both socially and ecologically sustainable [7].

While organic rice in Indonesia was starting to develop, it was affected by a number of factors. One of the main factors was the public's need for the type of food that provided health insurance. Farmers were starting to restructure rice production according to changing market needs. The increasing demand for organic rice was not only promoting healthy food, but was also allowing for environmental protection.

The development of organic rice in Indonesia was still managed using low yield agricultural technology, so it was necessary to identify productivity behavior and its components. Organic rice production could be made more efficient by achieving more output at current input levels. This could be done by identifying productivity behavior and its components. The concept of efficiency played an important role in increasing the organic rice yield and was widely recognized by researchers and policymakers. This research aimed to assess resource productivity and evaluate the technical 
efficiency of organic and inorganic rice production and determine the main factors that affect technical efficiency (TE).

\section{MATERIALS AND METHODS}

\section{A. Description of the research area and} techniques of data collection

The research was done in Central Sulawesi, Indonesia, which is located between $2^{0} 22$ 'North Latitude and $3^{\circ} 48^{\prime}$ South Latitude and between $119^{0} 22$ '- $124^{0} 22^{\prime}$ East Longitude. This province has land at various heights above sea level, namely: 0 $\mathrm{m}-100 \mathrm{~m}=20.2 \%, 101 \mathrm{~m}-500 \mathrm{~m}=27.2 \%, 501 \mathrm{~m}-$ $1000 \mathrm{~m}=26.7 \%$, and $1,001 \mathrm{~m}$ and above $=25,9 \%$. Central Sulawesi consists of 12 regencies and 1 city with a total area of $61,841.29 \mathrm{~km}^{2}$. The temperature in this province ranges from $27{ }^{\circ} \mathrm{C}-28{ }^{\circ} \mathrm{C}$ and rainfall is $71.7 \mathrm{~mm}-217.8 \mathrm{~mm}$ [8].

This research used cross-sectional data from lowland rice farmer households. Primary data were collected using a questionnaire from May to August 2020. Data on production input and output collected were: harvested area, fertilizer, number of seeds, labor, and amount of rice. Also, variables that caused variations in technical efficiency in lowland rice production were also collected, such as manager's age, manager's gender, manager's education, extension contacts, number of family members, types of seeds used, and the lowland rice cultivation system applied by farmers. The research location was selected purposively in Palolo and Torue sub-districts because these sub-districts were found to be organic lowland rice cultivation regions. The numbers of samples used were based on 249 lowland rice cultivation farms. The samples of organic lowland rice cultivation were selected purposively, being taken from 106 farmers, and 143 farmers were randomly selected for samples of inorganic lowland rice cultivation.

\section{B. Specification of the empirical model}

The methodological tool to achieve the objectives of this research was the stochastic frontier analysis. Stochastic production frontier measured business efficiency which was affected by factors outside the farmer's control because it could be taken into account as the inefficiency of these factors and errors during measurement.

Lowland rice production in the research area was likely to be affected by several factors that were beyond the farmer's control, such as natural disasters and pests, besides that, measurement errors could not be avoided. Based on this, we used the stochastic production frontier to achieve the research objectives. We used the Cobb-Douglas model of stochastic production frontier described by Coelli et al [9]:

$$
\begin{gathered}
\ln q_{i}=\beta_{0}+\beta_{1} \ln x_{i}+v_{i}-u_{i} \quad(1) \text { or } \\
q_{i}=\exp \left(\beta_{0}+\beta_{1} \ln x_{i}\right) \cdot \exp \left(v_{i}\right) \cdot \exp \left(-u_{i}\right)
\end{gathered}
$$

where $\mathrm{q}_{\mathrm{i}}$ represents the output of the $\mathrm{i}^{\text {th }}$ cultivation; $\mathrm{x}_{\mathrm{i}}$ is the input from the $\mathrm{i}^{\text {th }}$ cultivation; $\beta$ is the parameter to be estimated; $v_{i}$ is a statistical disturbance and $u_{i}$ reflects the technical inefficiency of lowland rice cultivation. The measure of technical efficiency (TE) is the ratio of the observed output to the stochastic frontier output:

$$
T E_{i}=\frac{q_{i}}{\exp \left(x_{i} \beta+v_{i}\right)}=\frac{\exp \left(x_{i} \beta+v_{i}-u_{i}\right)}{\exp \left(x_{i} \beta+v_{i}\right)}=\exp \left(-u_{i}\right)
$$

TE values range between zero and one.

TE of lowland rice production in Central Sulawesi was measured by considering the output obtained per farmer as the dependent variable. The yield of lowland rice cultivation was measured in tonnes. The independent variable is the production input used by farmers in lowland rice cultivation, so the formula is written as follows:

$\ln Y=\beta_{0}+\sum_{i=1}^{5} \beta_{j} \ln X_{i j}+v_{i}-u_{i}$

Where: $\mathrm{Y}=$ rice produced (tonnes) by the $\mathrm{i}^{\text {th }}$ farmer; $\mathrm{X}_{1}=$ lowland rice harvested area (ha) by the $\mathrm{i}^{\text {th }}$ farmer; $X_{2}=$ number of fertilizer $(\mathrm{kg})$ used by the $\mathrm{i}^{\text {th }}$ farmer; $X_{3}=$ number of lowland rice seeds $(\mathrm{kg})$ used by the $i^{\text {th }}$ farmer; $X_{4}=$ number of labor (days of people work) used by the $i^{\text {th }}$ farmer.

Technical inefficiency $\left(\mathrm{u}_{\mathrm{i}}\right)$ can be defined in the following equation:

$u_{i}=\lambda_{0}+\sum_{k=1}^{7} \lambda_{k} Z_{j k}$

Where: $\mathrm{Z}_{1}=$ manager's age (years); $\mathrm{Z}_{2}=$ manager's gender ( 1 if male, 0 otherwise); $Z_{3}=$ manager's education (years); $Z_{4}=$ extension contacts (frequency); $Z_{5}=$ number of family members (soul); $Z_{6}=$ superior seeds $(1$ if the seed is superior, 0 otherwise); $\mathrm{Z}_{7}=$ organic lowland rice cultivation (1 if organic, 0 otherwise).

\section{III.RESULTS AND DISCUSSION \\ A. Factors of Lowland Rice Production}

The parameter estimations of the Cobb-Douglas model stochastic production frontier are presented in Table 1.

Table 1 Parameter estimation of the Cobb-Douglas production function

\begin{tabular}{lccc}
\hline \multirow{2}{*}{ Variable } & \multicolumn{3}{c}{ Maximum likelihood estimate } \\
\cline { 2 - 4 } & $\begin{array}{c}\text { Paramete } \\
\mathrm{r}\end{array}$ & Coefficient & $\begin{array}{c}\text { Standar } \\
\mathrm{d} \text { error }\end{array}$ \\
\hline Intercept & $\beta_{0}$ & 4.377 & 0.165 \\
InLand & $\beta_{1}$ & $0.183^{* *}$ & 0.051 \\
InFertilizer & $\beta_{2}$ & $0.211^{* *}$ & 0.043 \\
InSeed & $\beta_{3}$ & $0.196^{* *}$ & 0.040 \\
InLabor & $\beta_{4}$ & $0.345^{* *}$ & 0.055
\end{tabular}




\begin{tabular}{|c|c|c|c|}
\hline sigma-squared & $\mathrm{v}_{\mathrm{i}}$ & $0.025 * *$ & 0.003 \\
\hline gamma & $\mathrm{u}_{\mathrm{i}}$ & $0.965 * *$ & 0.010 \\
\hline $\begin{array}{l}\text { log likelihood function } \\
\text { LR test of the one-sided } \\
\text { error } \\
\text { mean efficiency }\end{array}$ & & $\begin{array}{c}415.140 * * \\
0.782= \\
78.2 \%\end{array}$ & \\
\hline
\end{tabular}

Note: $* *$ significant at $\alpha 1 \%$

Table 1 shows that the four variables considered in the production function (land, fertilizer, seed, and labor) had a significant effect in explaining variations in rice production at the farming level. The four variables considered were positive and significant at the $1 \%$ level. This suggested that land, fertilizer, seed, and labor were still important in explaining lowland rice production in the research area. Given that the form of the production function is Cobb-Douglas, the coefficient value directly reflected its elasticity. The positive production elasticity from land, fertilizer, seed, and labor indicated that each increase in these variables would increase the yield of lowland rice. With the increase in land allocation for lowland rice, the number of fertilizer applications, the number of seed applications, and the labor by $1 \%$ each, the lowland rice production could increase by $0.18 ; 0.21 ; 0.20$; and $0.35 \%$. This research is in line with the research of Effendy [10] and Antara \& Effendy [11] who stated that land, fertilizer, seed, and labor were important production factors that supported lowland rice yields.

\section{B. Technical Efficiency (TE)}

The average technical efficiency achieved by farmers in lowland rice production in the research area was 0.782 . This suggested that the average productivity achieved was $78.2 \%$ of the frontier, namely the maximum productivity that could be achieved with the best management system at that time.

The distribution of lowland rice farmers according to the level of technical efficiency can be seen in Figure 1.

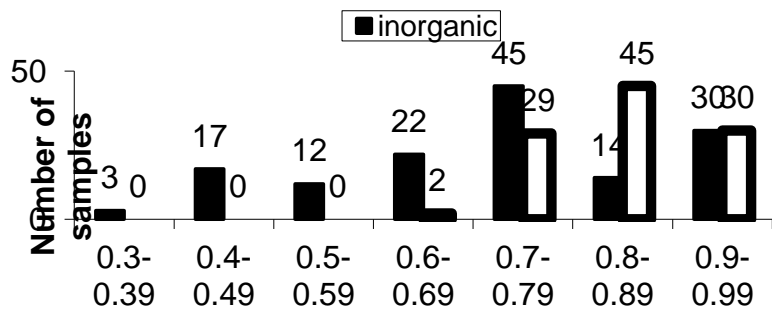

\section{Fig 1. Technical efficiency level}

Figure 1 shows that the level of technical efficiency of organic lowland rice farmers was higher than inorganic lowland rice farmers. The level of technical efficiency of organic lowland rice farmers ranged from 0.6 to 0.99 and inorganic lowland rice farmers ranged from 0.3 to 0.99 . The proportion of farmers who were close to the frontier (TE 1) was around $24 \%$ and those below 0.6 was around $13 \%$, this showed that there was still a chance for farmers to increase productivity with the resources they have. To achieve this, better managerial skills were required. Mastery of information and decision making in managing production factors had to be improved. Farmers who had a technical efficiency level close to 1 had little chance to increase productivity. To increase the productivity of farmers, more advanced technological innovations were needed than the existing ones.

\section{The Determinant of Technical Efficiency}

The stochastic production frontier estimation results in Table 1 show the gamma value of 0.965 and significant at the $1 \%$ level, this reflected that random errors that could not be explained in the production function model could be explained in the inefficiency function. The variables that were thought to affect the technical efficiency of lowland rice cultivation are listed in Table 2.

Table 2 Parameters estimation affected technical inefficiency

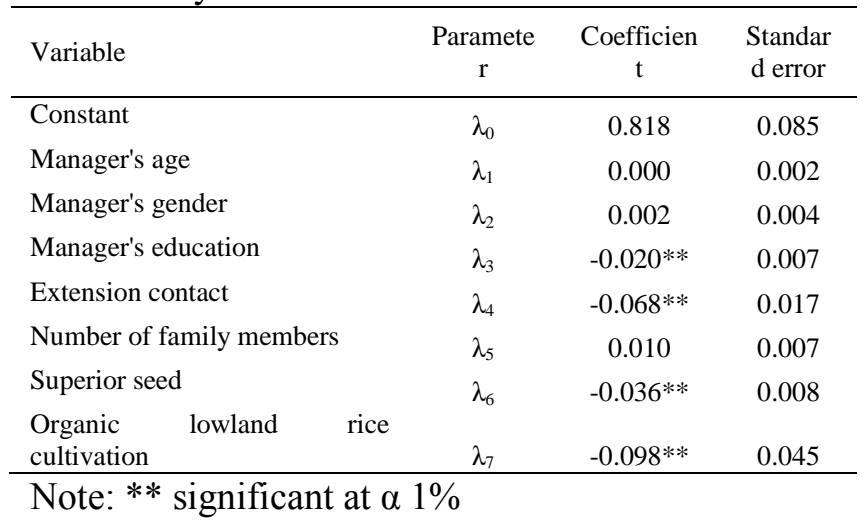

Table 2 shows that of the seven variables thought to affect technical efficiency, only four variables were significant, namely manager's education, extension contact, superior seed, and organic lowland rice cultivation. The coefficient of these variables was negative and significant at the $1 \%$ level, this implied that improving these variables would increase technical efficiency in lowland rice production. 


\section{C.1 Manager's Education}

The results showed that the level of manager's education had a significant effect on the level of technical efficiency of lowland rice cultivation. The education coefficient had a negative and significant effect at the $1 \%$ level. This meant that farmers with higher education reached relatively higher levels of technical efficiency. Education could increase the farmer's insight in seeking more advanced agricultural technology information. Education gave farmers the ability to manage information from various sources and apply new technologies to lowland rice cultivation so they could increase the yields. Educated farmers were able to adopt better technology such as superior seed, fertilizer, and pesticide much faster than those without education. These results are in line with the findings of Ali \& Khan [12] and Alemu et al [13] who stated that education could increase the productivity of human resources (farmers).

\section{C.2 Extension Contact}

Extension contact had a significant effect on the level of technical efficiency in lowland rice production. The sign of extension contact coefficient was negative and significant at the $1 \%$ level. This implied that farmers who frequently followed in agricultural extension would reduce the effects of technical inefficiency in lowland rice production. Farmers who often followed in lowland rice agricultural extension tended to have a higher level of technical efficiency than those who did not. This finding is in line with the arguments of Ahmed et al [14], Effendy et al [15, 16], Emmanuel et al [17] and Mann \& Warner [18] which showed that the extension provided would increase the productivity of farmers and suppress the effects of unwanted technical inefficiencies. The extension was informal education that could build the managerial capacity of a farmer. Farmers who followed in the lowland rice agricultural extension were faster to adopt better technology than those who did not follow the extension. Farmers in the research area often received lowland rice agricultural extension services; for example, gained lowland rice cultivation techniques, learned better pest and disease control, and gained overall better harvest and post-harvest results.

\section{C.3 Superior Seed}

Superior seed was stated in dummy variables (1 if superior seeds and 0 if otherwise). The sign of superior seeds coefficient was negative and significant at the $1 \%$ level in affecting the level of technical efficiency of farmers in lowland rice production. Lowland rice cultivation that used superior seed was more efficient than farmlands that were using local seeds. The results of this research are consistent with the findings of Effendy et al [15], Bhatt \& Bhat [19], and Dessale [20] who stated that superior seed could suppress technical inefficiencies in agricultural production. The use of superior seeds in lowland rice cultivation could reduce the effect of technical inefficiency so that the maximum productivity tended to be achieved. This implied that the increase in lowland rice production depended on the type and quality of seeds available.

\section{C.4 Organic Lowland Rice Cultivation}

Organic lowland rice cultivation in this research was stated as a dummy variable ( 1 if organic and 0 if otherwise). The sign of organic lowland rice cultivation coefficient was negative and significant at the $1 \%$ level. This showed that organic lowland rice cultivation could reduce the effects of technical inefficiency in lowland rice production. Farmers who cultivated organic lowland rice tended to have a higher level of technical efficiency, this implied that organic materials could increase soil productivity so that the effect of technical inefficiency could be suppressed [15].Organic materials from manure and leaves could increase the nitrogen and organic $\mathrm{C}$ content in the soil. Returning rice straw in lowland rice cultivation could increase the potassium content. Rice straw is a good source of macronutrients [21].

\section{CONCLUSION}

The technical efficiency of lowland rice cultivation could be increased through better management of the resources owned by farmers, especially those resources like the land, fertilizer, seed, and labor. To increase technical efficiency in lowland rice production, the productivity of farmers should be increased in managing production factors. Increasing productivity of farmers in their organizations makes it necessary to pay attention to their education, participation in extension, the seeds used, and applied cultivation. Education status also proved relevant and research results show that managers with higher education were better able to deal with efficiency in the lowland rice production process. This implied that efforts were needed to increase the knowledge of low-educated farmers through extension services. Extension positively and significantly affected technical efficiency in lowland rice production. It was necessary to provide extension for farmers because it could increase their knowledge in the use of superior seeds, organic materials, and post-harvest handling. The use of 
superior seeds and organic materials in lowland rice cultivation could suppress inefficiencies in production, so that the results could reach the frontier.

\section{REFERENCES}

[1] Cui N, Cai M, Zhang X, Abdelhafez AA, Zhou $\mathrm{L}$, Sun H, et al., Runoff loss of nitrogen and phosphorus from a rice paddy field in the east of China: Effects of long-term chemical N fertilizer and organic manure applications, Glob Ecol Conserv, 2020, pp. e01011.

[2] Suhardianto A, Baliwati YF, Sukandar D. Ketahanan pangan rumah tangga petani penghasil beras organic, J Gizi Dan Pangan, Vol. 2, No. 3, 2007, pp.1-12.

[3] Zhao J, Ni T, Li J, Lu Q, Fang Z, Huang Q, et al., Effects of organic-inorganic compound fertilizer with reduced chemical fertilizer application on crop yields, soil biological activity and bacterial community structure in a rice-wheat cropping system, Appl Soil Ecol, Vol. 99, 2016, pp. 1-12.

[4] Navaranjan G, Hohenadel K, Blair A, Demers PA, Spinelli JJ, Pahwa P, et al., Exposures to multiple pesticides and the risk of Hodgkin lymphoma in Canadian men, Cancer Causes Control, Vol. 9, 2013, pp. 1661-1673.

[5] Slusky DA, Metayer C, Aldrich MC, Ward $\mathrm{MH}$, Lea CS, Selvin S, et al, Reliability of maternal-reports regarding the use of household pesticides: Experience from a case-control study of childhood leukemia. Cancer Epidemiol, Vol. 36, No. 4, 2012, pp. 375-380.

[6] Al-Taie WAA, Rahal MKM, AL-Sudani ASA, AL-Farsi KAO, Exploring the Consumption of Organic Foods in the United Arab Emirates, SAGE Open, Vol. 5, No. 2, 2015, pp.1-12.

[7] Chouichom, S., Yamao, M, Comparing opinions and attitudes of organic and nonorganic farmers towards organic rice farming system in North-Eastern Thailand, J Org Syst, Vol. 5, No. 1, 2010, pp. 25-35.

[8] BPS, Provinsi Sulawesi Dalam Angka. BPS Provinsi Sulawesi Tengah, 2018.

[9] Coelli T, Rao DSP, Battese GE, An Introduction to Efficiency and Productivity Analysis [Internet]. Boston, MA: Springer US; 1998 [cited 2020 Oct 4]. Available from: http://link.springer.com/10.1007/978-1-46155493-6

[10] Effendy, Efisiensi faktor produksi dan pendapatan padi sawah di Desa Masani
Kecamatan Poso Pesisir Kabupaten Poso, $J$ Agroland, Vol. 17, No. 3, 2010, pp. 233-40.

[11] Antara M, Effendy, Allocation Optimization of Farmers' Resources to Achieve Maximum Income in Parigi Moutong Regency, Asian J Sci Res, Vol. 11, No. 2, 2018, pp. 267-75.

[12] Ali S, Khan M, Technical Efficiency of Wheat Production in District Peshawar,Khyber Pakhtunkhwa, Pakistan, Sarhad J Agric, Vol. 30, No. 4, 2014, pp. 433-41.

[13] Alemu MD, Tegegne B, Beshir H, Technical Efficiency in Teff (Eragrostisteff) Production: The Case of Smallholder Farmers in Jamma District, South Wollo Zone, Ethiopia, J Agric Econ Rural Dev, Vol. 4, No. 2, 2018, pp. 5139.

[14] Ahmed B, Haji J, Geta E, Analysis of Farm Households' Technical Efficiency in Production of Smallholder Farmers: The Case of Girawa District, Ethiopia, Am-Eurasian $J$ Agric Env Sci, Vol. 13, No. 12, 2013, pp. 1615-21.

[15] Effendy, Pratama MF, Rauf RA, Antara M, Basir-Cyio M, Mahfudz, et al., Factors influencing the efficiency of cocoa farms: A study to increase income in rural Indonesia, PLOS ONE, Vol. 14, No. 4, 2019, pp. $\mathrm{e} 0214569$.

[16] Effendy E, Hanani N, Setiawan B, Muhaimin AW, Effect Characteristics of Farmers on the Level of Technology Adoption Side-Grafting in Cocoa Farming at Sigi Regency-Indonesia, $J$ Agric Sci, Vol. 5, No. 12, 2013, pp. 72-7.

[17] Emmanuel D, Owusu-Sekyere E, Owusu V, Jordaan $\mathrm{H}$, Impact of agricultural extension service on adoption of chemical fertilizer: Implications for rice productivity and development in Ghana, NJAS - Wagening J Life Sci, Vol. 79, 2016, pp. 41-9.

[18] Mann ML, Warner JM, Ethiopian wheat yield and yield gap estimation: A spatially explicit small area integrated data approach, Field Crops Res, Vol. 201, 2017, pp. 60-74.

[19] Bhatt MS, Bhat SA, Technical efficiency and farm size productivity-micro level evidence from jammu \& Kashmir, Int J Food Agric Econ, Vol. 2, No. 4, 2014, pp. 27-49.

[20] Dessale M. Analysis of technical efficiency of small holder wheat-growing farmers of Jamma district, Ethiopia, Agric Food Secur, Vol. 8, No. 1, 2019, pp. 1-8.

[21] Bu R, Ren T, Lei M, Liu B, Li X, Cong R, et al., Tillage and straw-returning practices effect on soil dissolved organic matter, aggregate fraction and bacteria community under ricerice-rapeseed rotation system, Agric Ecosyst Environ, Vol. 287, 2020, pp. 106681. 


\section{Creative Commons Attribution}

\section{License 4.0 (Attribution 4.0}

International, CC BY 4.0)

This article is published under the terms of the Creative Commons Attribution License 4.0

https://creativecommons.org/licenses/by/4.0/deed.en _US 